\title{
Eucalypts for Tropical Rainforest (Af) climate
}

\author{
Arno Brune
}

GPPusaka, 1st and 2nd Floor, Lot 7542-7546, Medan Central Commercial Centre, (Phase 2), Jalan Tanjung Kidurong, 97000, Bintulu, Sarawak, Malaysia, E-mail: arnobrune@hotmail.com

\begin{abstract}
The equatorial region of the world includes areas of Tropical Rainforest (Af) and Tropical Monsoon (Am) climate zones, which are distinguished by high temperatures and high rainfall, but soils which are often deficient. Potential productivity of plantation forestry in this area is high, and so are the pest and disease dangers which threaten it. This paper describes the Eucalyptus and Corymbia species which are adapted to this situation and also resistant to the main diseases like leaf blights. Based on the highly adapted E. biterranea and E. deglupta and several more, hybridization combined with vegetative propagation is discussed as an excellent alternative to obtain quick gains in short rotations while maintaining wide genetic diversity in such plantations. Management remedies are given for the possible backlash of quick soil depletion.
\end{abstract}

Keywords: Rainforest climate, Eucalyptus, Corymbia, vegetative propagation, hybridization, adaptation, productivity, plantations

\section{Introduction}

Köppen-Geiger classified the climates of the world regarding the vegetation (Table 1). Each climate was defined by three letters: the first defines the kind the plants of each zone ( $A$ - equatorial zone; $\mathrm{B}$ - arid zone; C - warm temperate zone; D - snow zone; and $\mathrm{E}$ - polar zone) the second refers to the precipitation, and the third to the temperature) (Kottek et al. 2006).
Table 1

Tropical, arid and temperate climates

\begin{tabular}{|c|c|c|}
\hline $\begin{array}{c}1^{\text {st }} \text { letter } \\
\text { (vegetation) }\end{array}$ & $\begin{array}{l}2^{\text {nd }} \text { letter } \\
\text { (rainfall) }\end{array}$ & $\begin{array}{c}3^{\text {rd }} \text { letter } \\
\text { (temperature) }\end{array}$ \\
\hline \multirow[t]{4}{*}{ A (tropical) } & $f$ (Rainforest) & \\
\hline & m (Monsoon) & \\
\hline & w (Savanna, Dry winter) & \\
\hline & s (Savanna, Dry summer) & \\
\hline \multirow[t]{4}{*}{$\mathrm{B}$ (arid) } & W (Desert) & \\
\hline & S (Steppe) & \\
\hline & & h (Hot) \\
\hline & & k (Cold) \\
\hline \multirow[t]{6}{*}{ C (temperate) } & w (Dry winter) & \\
\hline & f (No dry season) & \\
\hline & s (Dry summer) & \\
\hline & & a (Hot summer) \\
\hline & & b (Warm summer) \\
\hline & & c (Cold summer) \\
\hline
\end{tabular}

The Af climate, as defined in the Köppen-Geiger classification (Kottek et al. 2006), is a climate with temperatures always above $18{ }^{\circ} \mathrm{C}$ and monthly minimum precipitation above $60 \mathrm{~mm}$ (Figure 1). This equatorial climate occurs in several areas around the world, notably in the central and eastern Amazon area, the Guyanas, western Colombia and Panama, central DRC, peninsular Malaysia, the island of Borneo, Sumatra and western Java, Sulawesi and a major part of northern Papua and Papua-New Guinea, New Britain, Solomon Islands and several more Pacific islands, generally spanning latitudes $10^{\circ}$ north and south of the equator (Köppen-Geiger classification Map, 2016). 


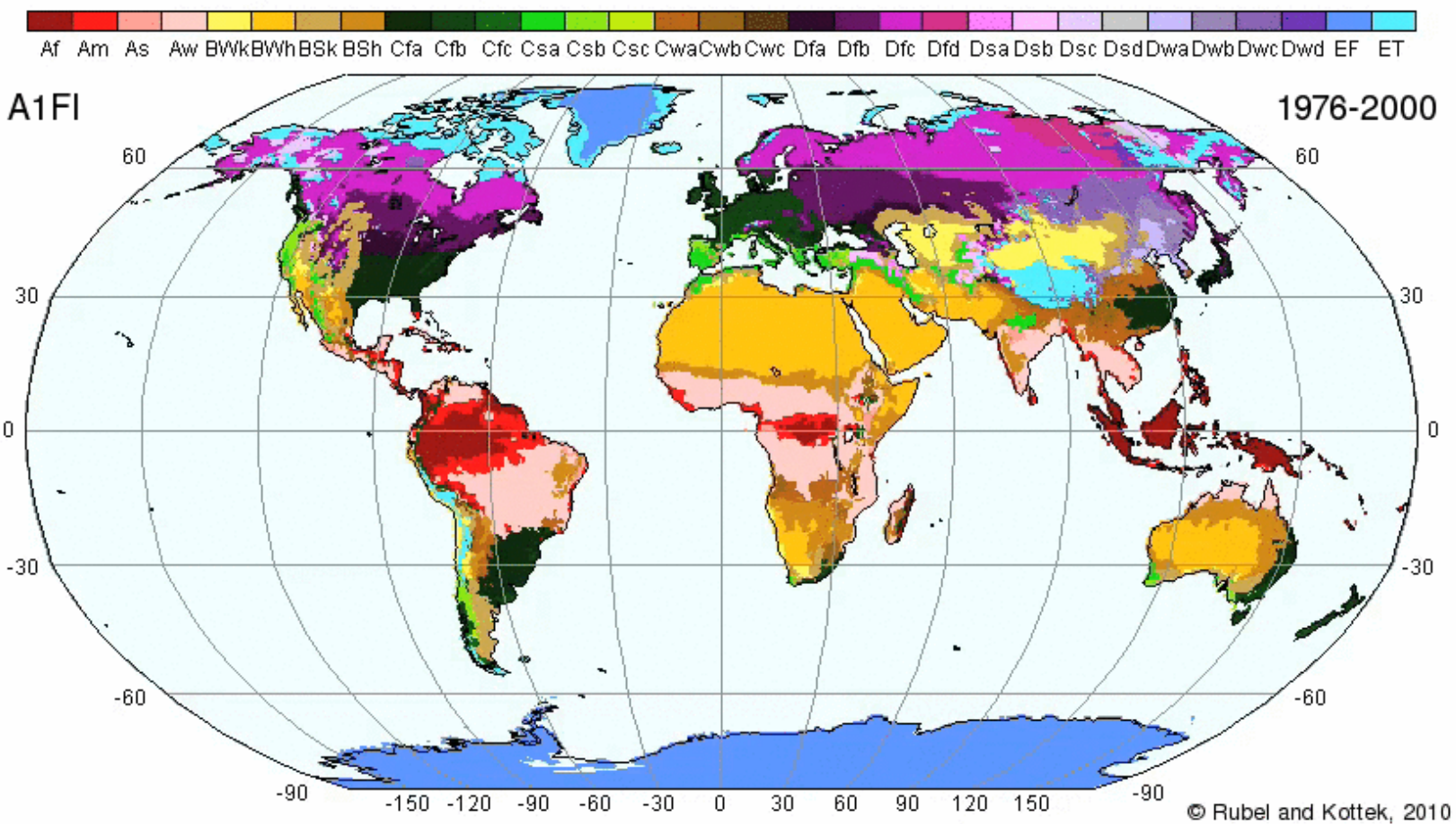

Figure 1

The Köppen-Geiger Classification Map (from http://koeppen-geiger.vu-wien.ac.at with the kind permission from Prof. Dr. F. Rubel - 15.3.2021).

The soils are generally weathered and leached ultisols and oxysols with severe nutrient deficiencies but can contain fertile volcanic soils and alluvial soils. Areas with these climates generally host luxuriant native vegetation, due to the favourable temperature and abundance of water. Plants which evolve under such conditions usually do not adapt to areas with a clear dry season and/or a period with lower temperatures.

Plant diseases usually thrive under these conditions as well. Co-evolution of plants and parasites may have led to some tolerance or resistance of the plants to the native diseases.

Important crop plants from Af areas have been spread to similar areas around the world, and have become of high importance to many local economies. That is the case of the cacao tree (Theobroma cacao), rubber tree (Hevea brasiliensis), oil palms (Elaeis guineensis and Elaeis oleifera) and several banana species (Musa spp.).

Thirty-one percent of the global land surface areas are covered with forests -3.99 billion hectares (Payn et al. 2015); of these $20.1 \%$ are in Russia, $12.2 \%$ in Brazil, $8.5 \%$ in Canada, 7.6 $\%$ in USA and $5.4 \%$ in China (FAO 2020). Seven percent - 291 million hectares - (Payn et al. 2015) of the total forests in the world are plantations (Evans 2009, Payn et al. 2015). Evans (2009) estimated that "planted forests contribute massively to industrial wood and fibre supply (potentially two thirds)" and that "Globally, $70 \%$ of forest products are sourced from $7 \%$ of the world's forest, of which the latter are predominantly planted". Buongiorno and Zhu (2014) from data of 2009, calculated that planted forests reduced roundwood harvesting globally from natural forests by $26 \%$. Brazil alone, aside from the sizable native forest in the Amazon area with Af climate, had 9 million hectares of planted forests in subtropical climates; $77 \%$ was eucalypts with 6.97 million hectares (IBÁ 2020). The percentage of extremely productive clonal eucalypt forests is not certain, but estimates are that it makes up $90 \%$ of eucalypts in that country. Planted forests with their high productivity help save native forests from being further depleted (Evans 2009, Buongiorno and Zhu 2014), even though there are other pressing economic and demographic reasons why these forests are often exploited.

Majer and Recher (1999) warn that large-scale exotic eucalypt plantations can be a threat to the biodiversity and environment. They do believe that fast rotation eucalypt plantations with high productivity are a way of diminishing the pressure on native timber exploitation but should not replace the native forest to such a degree that it becomes minimal, and hypothesize that native trees should be better for a plantation than exotic ones. They recommend that eucalypts in Brazil be planted in such a way as to allow for wildlife corridors between blocks of native forests, as is commonly done in large eucalypt plantations in Brazil. Elias and Boucher (2014) state that fast wood plantations are expanding worldwide at a rate of 0.8-1.2 million hectares/year and will continue to do so over the next decades. They state that "the warm and wet tropics, where 
trees can grow virtually year-round, are an important region for fast wood monocultures" and also that clearing of natural forests for wood plantation is limited mostly to Southeast Asia, Indonesia in particular. They argue that by cultivating wood through sustainable forest management techniques, including properly managed plantations, the rise in demand should not affect the world's forests.

While native forest trees around the world commonly grow at a rate of $1-5 \mathrm{~m}^{3} / \mathrm{ha} /$ year (Payn et al. 2015), in productivity they stay way behind well managed eucalypt plantations in subtropical environments where productivity often exceeds $45 \mathrm{~m}^{3} / \mathrm{ha}$ /year. There are, of course, other high valued timber trees - native or not - which can do well in plantations, such as the native Ochroma pyramidale, balsa-wood in the Amazon area, with a productivity of $17 \mathrm{~m}^{3} / \mathrm{ha} /$ year in seven year rotations or the introduced Tectona grandis in Am climates of Amazonia with $10-15 \mathrm{~m}^{3} / \mathrm{ha}$ /year which demands good alkaline soils and is grown in 25 year rotations, which have to be thinned with some wood harvested earlier (Barbosa Filho, J. personal communication 2021). These are also produced in monoculture.

Extraordinary advances of productivity were attained in several countries and different climates - generally with a dry season and in subtropical conditions - with the genus Eucalyptus and more recently Corymbia, by using hybridization in conjunction with clonal propagation.

Hybridization and vegetative propagation are not the only means of genetic tree improvement. Another means which is progressing rapidly is genetic modification (OECD 2014). Considerable progress has recently been made by inserting genes for cold tolerance, salt tolerance, drought tolerance, decrease in lignin content and even disease resistance into eucalypts (OECD 2014). It is likely that for general adaptability, which depends on large gene blocks, traditional tree improvement based on selection and hybridization breeding will continue to be the main strategy.

The high productivity obtained by hybridization and cloning in subtropical regions begs the question if similar methods could not be applied in areas of Af climates as well.

\section{Eucalyptus}

Compared with over one thousand acacias in Australia alone, the 730 species of the genus Eucalyptus are fewer (Nicolle and Jones 2018) but they include dozens of species with wide adaptability in many climates, while there is only a handful of plantation acacias (Table 2).

The genus Eucalyptus includes 470 species within the very large subgenus Symphyomyrtus, where most of the planted eucalypts reside, but there are more in different subgenera. Symphyomyrtus is divided into 11 sections (Nicolle and Jones 2018). Most planted eucalypts are included within the three sections Latoangulata, Exsertaria and Maidenaria. These sections include eucalypt species for tropical, sub-tropical, arid zone climates, monsoon and Mediterranean areas and coldhardy ones. Wood qualities also vary; there are very high and low density woods, splitting and non-splitting woods, suitable for high-grade cellulose and soluble cellulose, energy, charcoal as reducing agents in the iron industry, mine poles and solid wood products. There is an extraordinary wide genotypic and phenotypic variability available.

All eucalypts have $2 n=22$ chromosomes and the vast majority of the species in the mentioned three sections can be hybridized with each other, often yielding hybrids with heterosis (Rezende et al. 2014), widening the phenotypic combinations for growth, resistance to different environments and diseases, as well as for wood properties. Interspecific hybridization is no guarantee for heterosis, but can also produce depressed and deformed offspring (Assis 2000, Potts et al. 2003). Therefore trial and selection is always necessary for each hybridization done.

Exclusively extra-Australian species include: E. binacag, $E$. deglupta, E. alba var. alba, E. sp., E. orophila, E. urophylla and E. wetarensis. The differentiation of E. binacag in Mindanao from E. deglupta is not generally known or accepted.

Australian and Extra-Australian species are: E. leptophleba, E. brassiana, E. tereticornis subsp. tereticornis, and E. biterranea. The naming of E. biterranea, being the north Queensland and PNG provenance of E. pellita is not generally known or accepted.

Table 2 includes $90-95 \%$ of the eucalypts used worldwide for plantations either as hybrids or species. They are: E. camaldulensis, E. dunnii, E. globulus, E. grandis, E. nitens, E. pellita, E. saligna, E. tereticornis and E. urophylla (Harwood 2011). The species composition is different, according to the region, purpose or climate, and often includes other species.

Ladiges (1997) established a phylogeny within the accepted six sections by Pryor and Johnson (1971) within the genus Symphyomyrtus. That phylogeny pointed to a close relationship between the sections Latoangulata (then known as Transversaria), Maidenaria and Exsertaria, a fact which Potts et al. (2003) showed to agree with the many hybrids done among the species in these sections.

Currently Nicolle and Jones (2018) recognize 11 sections within Symphyomyrtus. Potts et al. (2003) compiled a list of manipulated hybrids which had been produced between species of the formerly known sections as established by Pryor and Johnson (2071). Table 3 shows that most hybrids were between the sections Exsertaria, Latoangulata and Maidenaria, also between Maidenaria and Adnataria; Adnataria and Bisectaria; and Bisectaria and Dumaria. Latoangulata formerly was to a large degree known as Transversaria.

The possibility of crosses between the sections not yet made remains open. However, the further the species are separated botanically, the less likely they are to yield hybrids and more likely to produce dwarfs and plants otherwise unfit for growth (Potts et al. 2003). Assis (2000) found that within Sympyomyrtus, sections now known as Latoangulata (formerly Transversaria), Exsertaria and Maidenaria (Nicolle 2019) hybridize widely with each other, but the closer, the more heterosis one is likely to find, as generally within and between sections Latoangulata and Exsertaria; while species of Maidenaria yield some percentage of dwarfs and other abnormalities when crossed with other species of the same section or with species 
Table 2

Subdivision of some Eucalyptus species in the Subgenus Symphyomyrtus, according to Nicolle (2019)

\begin{tabular}{|c|c|c|c|c|}
\hline Subgenus & Section & Series & Subseries & Species \\
\hline Symphyomyrtus & Latoangulatae & Robustae & & urophylla \\
\hline " & “ & " & & biterranea \\
\hline " & " & " & & pellita \\
\hline “ & " & " & & robusta \\
\hline “ & " & Transversae & & saligna \\
\hline “ & “ & “ & & grandis \\
\hline “ & Equatoria & & & deglupta \\
\hline " & Exsertaria & Exsertae & Subexsertae & alba \\
\hline “ & “ & " & " & brassiana \\
\hline “ & " & “ & Erythroxylon & tereticornis ssp. tereticornis \\
\hline “ & “ & " & Rostratae & camaldulensis \\
\hline “ & Maidenaria & Remanentes & & nitens \\
\hline " & “ & Globulares & Euglobulares & globulus \\
\hline " & " & “ & " & bicostata \\
\hline “ & “ & " & " & pseudoglobulus \\
\hline “ & “ & " & " & maidenii \\
\hline " & “ & Bridgesianae & & dunnii \\
\hline “ & " & Viminales & Lanceolatae & viminalis \\
\hline " & " & “ & $"$ & benthamii \\
\hline
\end{tabular}

Table 3

Crosses made between the six sections recognized by Pryor and Johnson (1971) (adapted from Potts et al. 2003)

\begin{tabular}{lcccc}
\hline & Latoangulata & Exsertaria & Bisectaria & Dumaria \\
\hline Maidenaria & $\mathrm{x}$ & $\mathrm{x}$ & - & $\mathrm{A}$ \\
Latoangulata & & $\mathrm{x}$ & $\mathrm{x}$ & - \\
Exsertaria & & & - & - \\
Bisectaria & & & $\mathrm{x}$ \\
Dumaria & & & - \\
\hline
\end{tabular}

of Latoangulata. Still, in the crosses of species from Maidenaria with species from Latoangulata, among many offspring one finds frequent heterosis for growth (Assis 2000). Hybrid offspring are used in plantations by vegetative propagation, which captures additive and non-additive variance superiority. Dickinson et al. (2007) also found that within Corymbia, the closer the species, the higher the seed set and heterosis when hybridizing.

Progress made with vegetative eucalypt propagation was largely established in the last three decades of last century, and is now a technique widely applied everywhere where eucalypts are planted commercially (Assis et al. 2004, Assis 2006, 2011). This technique made it easy to capture and retain heterosis in hybrids, using additive and non-additive variance for mass propagation in plantations (Assis 2004, 2006; Resende et al. 2014, Rezende et al. 2014).

The hermaphroditic and androgynous characters of the Eucalyptus flowers are easy to be manipulated for hybridization (Rezende el al. 2014). However, it was the advent of hybridization by the artificially induced protogyny (AIP) (Assis et al. 2005) which stimulated vast programs in eucalypt hybridization. By this method it is easy, quick and very efficient to hybridize eucalypts (Dickinson et al. 2007), and it was quickly adopted worldwide.

The possibility of hybridization plus the ease of vegetative propagation (Assis et al. 2004, Harwood and Nambiar 2014a) offer an extraordinary opportunity to quickly breed new combinations of characters within the eucalypts with a wide possibility of adaptations. This fact led to many new combinations of characters which in turn is bringing quick progress to eucalypt culture through the production of new clones with heterosis, productivity, disease resistance and desired wood characteristics (Assis et al. 2004, Assis 2006, 2011). Production of many different hybrid combinations associated with testing and later a quick turnover of planted clones in plantations is crucial to obtain a wide array of different genotypes for adaptability associated to specific wood characteristics for the industry and for resistance breeding.

Due to the progress made with hybridization and plant production from minicuttings, eucalypts with high productivity are planted widely around the world in hugely differing climates, such as China, India, Indonesia, South Africa, Brazil, Portugal, Chile, Argentina, Uruguay, and others. Productivity often exceeds $35-45 \mathrm{~m}^{3} / \mathrm{ha}$ /year, up to $60 \mathrm{~m}^{3} /$ ha/year (Rezende et al. 
2014). This progress so far has been practically restricted to tropical and subtropical areas of the world, with a dry annual season which many species need to elicit flowering or escaping foliar blights and other diseases.

Planting of species which did not evolve in Af or Am climates makes them susceptible to many diseases when planted in such climates, especially leaf blights (Gonçalves et al. 2013, Rosa personal communication 2020). While the E. urophylla $\times E$. grandis hybrid clones are very productive in subtropical areas, the majority is not suited for Af and Am climates (Gonçalves et al. 2013). E. urophylla, E. camaldulensis, E. tereticornis, E. grandis, most clones of E. urophylla $x$ E. grandis were all seriously attacked by leaf blights in the Am climate of Amapá, Brazil, even though there is a distinct dry season (Rosa personal communication 2020). In peninsular Malaysia, E. camaldulensis planted in the 1980's grew well in the first years, but was totally abandoned in the 1990's due to leaf blights, as happened in Vietnam (Harwood 1998); but survived well in a climate in southern Vietnam with a distinct dry season (Harwood and Nambiar 2014a). In Thailand, in some very wet areas, E. camaldulensis succumbed to Kirramyces destructans and Cylindrocladium sp. leaf blights (Harwood and Nambiar 2014a).

Flowering behaviour is one of the signs of adaptation to a region and is also important for hybridization, although pollen can be transported from other regions. It is under genetic and environmental control with environmental conditions such as photoperiod, stress, a cold spell or a dry season triggering it. There are species which are very late in flowering, such as $E$. dunnii, which even in adequate climates usually flowers only from about age 20 onwards. Most species start flowering around age 3 years. Some other species, like Corymbia torelliana, for many years does not flower in Australia, while in Brazil and West Africa it is precocious in flowering and does so profusely every year. Species which in subtropical regions flower abundantly, when transferred to equatorial climates frequently do not (Harwood 1998). Rosa, A. (personal communication, 2020) states that in Amapá, Brazil, most E. urophylla, E. grandis, clones of E. urophylla $x$ E. grandis and E. camaldulensis do not flower. E. brassiana provenances from Australia did not flower, but those from PNG, from a similar climate as in the Amazon, flowered normally. E. pellita (actually E. biterranea) had a similar behaviour, with PNG provenances showing better adaptation in every sense. It must be stated that among both E. urophylla and E. urophylla $x$ E. grandis, a few clones and individuals are still resistant to diseases and also flower well (Rosa personal communication 2020), which attests to genetic differences among provenances and individual tree combinations. In this resides a source and potential for selection and hybridization for equatorial climates.

Rezende et al. (2014) state that expanding the range of commercial forests is as important as increasing its productivity. For Brazil this would mean advancing plantation forests from the current areas of Tropical savanna with dry winter (Aw); Dry winter humid sub-tropical (Cwa); Dry winter subtropical highland (Cwb); and Humid subtropical (Cfa) climates into the semi-arid Northeast (BSh climate) of the country and into the Amazonian region with Tropical rainforest (Af) and Tropical
Monsoon (Am) climates (Gonçalves et al. 2013). In the Northeast the limiting factor is low rainfall and high temperature, which can to a certain degree be improved by using drought-adapted species as found mainly in the section Exsertaria (e.g. E. camaldulensis, E. brassiana and E. tereticornis) as hybrids or pure species, but will not improve productivity over a certain level due to limited rainfall. However, for the Amazonian area, with constant (Af) or monsoonal (Am) rainfall during the year, productivity can be high.

Álvares et al. (2011), using the 3-PG model (Physiological Processes Predicting Growth) advanced predictions based on maximum, mean and minimum temperature data, relative humidity, solar radiation, relief and slope, soil natural fertility, rainfall and soil water holding capacity, of where planted forests would be productive and how much. Annual rainfall was the strongest factor related to productivity. For the semiarid Northeast, the maximum attainable productivity would be $25 \mathrm{~m}^{3} / \mathrm{ha}$ /year. But for the Amazonian region with Af and Am climates, which makes up over $40 \%$ of the country, the maximum potential productivity predicted exceeded $45 \mathrm{~m}^{3} / \mathrm{ha}$ / year. This area has a mean temperature of $>26^{\circ} \mathrm{C}$ (Queiroz et al. 2020). This is an extraordinary potential productivity on a very large area. Behling et al. (2011), also using the 3-PG model, predicted that in an area of Am climate at the eastern edge of the Amazon area, the current productivity of two clones ( $E$. pellita and $E$. urophylla) could be increased from the current 20 to 30 $\mathrm{m}^{3} / \mathrm{ha} /$ year, under appropriate fertilization and weed control practices.

Elli et al. (2020), using the APSIM Next Generation Eucalyptus model predicted that in future rainfall in the North (Amazonian) and Northeast Brazil would diminish, but temperature would increase everywhere due to current trends in climate change. This would also affect predictions about productivity. $\mathrm{CO}_{2}$ emissions tend to increase, theoretically improving photosynthesis under a higher temperature, provided that precipitation also increased. Using models to predict landscape change with changing climate, Gustafson et al. (2017) predicted that a moderate increase, up to $3{ }^{\circ} \mathrm{C}$ in temperature, might improve productivity of some species, however an increase of $6{ }^{\circ} \mathrm{C}$ would be detrimental, as it is offset by higher respiration and transpiration and also by a higher stomatal $\mathrm{CO}_{2}$ conductance resistance. With an increase of precipitation this might be somewhat mitigated, but predictions are that precipitation would come in short strong bursts with more dry periods in between, leading to less productivity in general, depending on the adaptation of individual species or clones to such a situation.

The mean optimum temperatures for growth of the nine most planted eucalypt species in the world were estimated by Harwood (2011) as given in Table 4.

When examining maximum, mean and minimum temperatures for growth of certain clones of E.urophylla $x$ E. grandis, $E$. grandis $x$ E. camaldulensis, E. urophylla $x$ E. tereticornis and three clones of $E$. benthamii and one of E. saligna, Queiroz et al. (2020) found that optimum mean temperatures for the clones of $E$. urophylla $x$ E. tereticornis, E. grandis $x$ E. camaldulensis and E. urophylla $\times$ E. grandis varied from $18-25^{\circ} \mathrm{C}$. For E. saligna it varied 
Table 4

Approximate range of mean annual temperature for good growth in plantations - from Harwood (2011)

\begin{tabular}{lc}
\hline \multicolumn{1}{c}{ Species } & Approximate range of mean annual temperature $\left({ }^{\circ} \mathrm{C}\right)$ for good growth in plantations \\
\hline E. camaldulensis & $18-28$ (northern provenances) \\
E. dunnii & $14-22$ \\
E. globulus & $9-18$ \\
E. grandis & $14-25$ \\
E. nitens & $9-18$ \\
E. pellita & $20-27$ \\
E. saligna & $14-23$ \\
E. tereticornis & $17-27$ \\
E. urophylla & $18-28$ \\
\hline
\end{tabular}

from $13-24{ }^{\circ} \mathrm{C}$, and for the $E$. benthamii clones from $11-24{ }^{\circ} \mathrm{C}$. These temperatures are in good agreement with Harwood's estimates who did not include $E$. benthamii; a species adapted to colder climates.

With mean temperatures above $26^{\circ} \mathrm{C}$, even over $30{ }^{\circ} \mathrm{C}$, equatorial Af and Am climates are not suitable for the hybrids given above, as the species and clones mentioned earlier find their optimum mean growth temperatures below this level and are adapted to a climate with a pronounced dry and/or cooler period. Productivity depends on the plants being healthy as well. However, a constantly wet, humid and hot situation leads to susceptibility to many diseases, especially leaf blights and Chrysoporthe cubensis in eucalypts (Harwood 1998, Harwood and Nambiar 2014a). Therefore, predictions about productivity in areas where species and clones are not satisfied as to climate requirements and disease resistances must be viewed critically. For hot and humid environments (Af and Am climates), species and clones adapted to those conditions must first be found or developed.

Assis (2015) mentions the following diseases and species resistant to them:

- Puccinia psidii: C. torelliana, E. camaldulensis, E. microcorys, E. pellita, E. pilularis, E. propinqua, E. resinifera E. robusta, E. salig $n a$, E. tereticornis and E. urophylla;

- Cylindrocladium sp. in northern Brazil: E. pellita, E. robusta and E. resinifera;

- Chrysoporte cubensis: C. citriodora, C. torelliana, E. cloeziana, E. pilularis, E. paniculata, E. pellita, E. urophylla and E. robusta.

Many of these species are not adapted to equatorial climates, where resistance to the diseases may break down while susceptibility to new ones can appear. Species which evolved in equatorial climates will better resist wet, hot conditions and adapt easier to increasing temperatures.

Therefore, in order to obtain highly productive and resistant eucalypts for equatorial climates a simple transfer of clones from subtropical areas is not sufficient; active breeding for such areas has to be done.

The species which evolved in Af climates and are superbly adapted to these conditions in growth and disease resistance are especially E. biterranea ("E. pellita" from PNG) and E. deglupta. In addition, E. brassiana, E. tereticornis var. tereticornis, E. alba var. alba and E. leptophleba are good candidates. E. urophylla, E. wetarensis and $E$. orophila stem from areas with a definite dry season or of higher elevations, but through hybridization can contribute adaptive genes to hot humid environments as well, as can the many species and clones now used in subtropical conditions.

\section{Eucalyptus biterranea (E. pellita from north Queensland and Papua)}

The northern Qld and PNG provenance of his species is referred to as E. biterranea, having been separated from E. pellita by Hill and Johnson (2000), based on morphology and molecular characters. It includes the "E. pellita" from northern Queensland, approximately north of $15^{\circ} \mathrm{S}$ and PNG provenances. House and Bell (1996) separated E. scias from E. pellita by isozyme studies, but saw no reason at that time to divide E. pellita into E. pellita and E. biterranea. For convenience, here we speak of E. biterranea or E. pellita from north Queensland and PNG as being the same species. It is classified as being part of the subgenus Symphyomyrtus, section Latoangulata, series Robustae, joining E. urophylla, E. pellita and E. robusta (Nicolle 2019). The section Latoangulata, series Transversae includes the wellknown species E. saligna and E. grandis (Nicolle 2019). All of these species can easily be hybridized with each other often resulting in considerable heterosis.

E. biterranea from PNG is well adapted to Af and to Am climates, and is resistant to a range of tropical diseases (Harwood and Nambiar 2014a). After Ceratocystis wilt decimated acacia plantations in Southeast Asia, it is the preferred species for planting, growing well in Indonesia, Malaysia and the Amazon area. At age 5 years in Sabah on Borneo Island it had a density of $629 \mathrm{~kg} / \mathrm{m}^{3}$ (Japarudin et al. 2020). In the Amazon area it is a preferred species for planting and for hybridization (Rosa, A. personal communication 2020). In all these areas E. pellita from PNG or E. biterranea, outperforms E. pellita from Australia. It usually occurs on lowland in rainfall areas of 1,000-3,000 $\mathrm{mm}$ a year with dry seasons varying from 0-5 months and an altitude of 0-800 $\mathrm{m}$ asl (Harwood 2018). A remarkable fact for the breeder is that the PNG provenances often have a high degree of inbreeding, with outcrossing around $50 \%$ (House and Bell 1996, Harwood 2018). This is unusual in the eucalypts, which 
normally have an outcrossing rate of $70 \%$ to over $90 \%$. The fairly low outcrossing rate in the original populations may be due to the small isolated populations which underwent inbreeding. Hence, a considerable genetic gain in the first generation of improvement can be due to outcrossing which occurs in the seed orchards. In subsequent generations of improvement the gains obtained by outcrossing will probably be lower.

Since E. biterranea (or northern Queensland and PNG E. pellita) evolved and thrives in equatorial climates, it is much better equipped to cope with the higher temperatures, humidity and diseases common in these environments, than are the species used in subtropical regions, which need lower temperature means and a definite dry season. This is being attested widely in Indonesia, Malaysia, and Vietnam and in the Amazon area. However, hybridization with many of the species from subtropical regions, such as E. urophylla, E. grandis, E. brassiana, E. camaldulensis, E. tereticornis etc. and their hybrids will infuse useful genes for improving productivity and add to specialized uses of the wood. While E. biterranea is easy to root from coppice shoots, it does have a sizable amount of bark (8-14\%), which can be improved through selection and hybridization. Therefore, E. biterranea will be one of the main species and partner for hybridization for Af and also Am climates, if the productivity hypothesized for hot and humid environments (Álvares et al. 2011) is to be achieved.

E. biterranea is not free of diseases. Ceratocystis fimbriata has in a few cases been found in Southeast Asia on E. biterranea. Arseni et al. (2016) in East Kalimantan found several leaf diseases associated to E. biterranea, but none of them damaging the trees. However, attention with pests and diseases is warranted.

\section{Eucalyptus deglupta}

This species, also belonging to the subgenus Symphyomyrtus, is placed into the section Equatoria by Nicolle (2019), where it stands alone or, if one accepts this division, together with $E$. binacag. In the present paper E. deglupta and E. binacag will be treated as being one species.

E. deglupta has a much wider natural distribution than does $E$. biterranea. It spans "between tropical latitudes from $9^{\circ} \mathrm{N}$ to $11^{\circ} \mathrm{S}$ in a markedly discontinuous distribution through eastern and southern Mindanao in the Philippines, Sulawesi, northern coast of Seram Island, West Papua and Papua provinces, PNG including West Sepik Province, central highlands, eastern coastal lowlands of the mainland and most of the island of New Britain" (Davidson et al. 2018). The full altitudinal range is from sea level to $2,500 \mathrm{~m}$ asl and annual rainfall distribution of 2,500-5,000 mm, growing best on alluvial soils and below 150 $\mathrm{m}$ asl, but also on volcanic ash (Davidson et al. 2018, Davidson, J. personal communication 2020). E. deglupta grows to $60 \mathrm{~m}$ in height, and can reach $80 \mathrm{~m}$ with $3 \mathrm{~m}$ dbh, is cylindrical and selfpruning, often with buttresses (Davidson et al. 2018). With such a diverse and discontinuous distribution, it is expected that there are differences between the many possible provenances. Cossalter (1975) examined and characterized 30 provenances on the island of Sulawesi and 10 on Seram. On Sulawesi the species crosses the equator, being the only eucalypt species native north of the equator, up to Mindanao in the Philippines. The wood is of low density in plantations, from $300-400 \mathrm{~kg} / \mathrm{m}^{3}$, increasing in density with age. The wood usually does not split. Bark is very thin, about $2 \mathrm{~mm}$ thick, shedding off in small flakes which gives the trunk a multi-colored aspect and hence the species is often referred to as "rainbow gum" or Mindanao gum. Due to the thin bark it is very fire sensitive. The wood is used for furniture, flooring and many purposes, including for a strong sulphate paper (Davidson et al. 2018). The species is not easy to graft or to coppice when cut down. When girdled, shoots are usually produced in lower numbers than for other species but the shoots are easy to propagate by vegetative means. Air-layering for establishment of clonal seed orchards works very well. Even though in its native habitat it is rarely exposed to more than three dry months (Cossalter 1975); in Ghana it thrived and withstood severe droughts of five to six months. Chaplin (1993) states that on the Solomon Islands this species has a MAI between 20 and $40 \mathrm{~m}^{3} /$ ha/year.

Vigneron et al. (2000) report that the crosses E. pellita $x E$. deglupta and E. urophylla $x$ E. deglupta produced mostly dwarfs. In the 1990's a breeding program in Mindanao was quite successful, and excellent hybrids were produced with E. urophylla and E. pellita (E. biterranea?) (Glori, 1993), increasing wood density and showing resistance to the varicose borer (Agrilus sexignatus), leaf blights and kino veins.

Due to the small size of the $E$. deglupta flower buds, the species is recommended to be used as the seed parent, as its pollen tubes might not reach the ovaries in the styles of largerflowered eucalypts. However, in the Philippines they claimed to have obtained crosses in both ways with E. pellita; using $E$. deglupta as seed bearer and as pollen donor as well (Glori 1993). It is not clear if in the Congo the same hybrids were produced with E. deglupta as pollen donor.

In spite of E. deglupta standing as the only representative in the section Equatoria (Nicolle 2019) it seems to easily produce hybrids with several other representatives in Symphyomyrtus. A spontaneous hybrid with E. camaldulensis which occurred in Thailand, called K7, was very successful there, in Laos (Ito 2009) and Vietnam. It had a wood density of $490 \mathrm{~kg} / \mathrm{m}^{3}$, better fiber qualities than $E$. camaldulensis and withstood droughts of 5 months (Ito 2009). Later it proved susceptible to the introduced gall wasp Leptocybe invasa and was eliminated (Harwood and Nambiar 2014a). Since E. camaldulensis belongs to the section Exsertaria, this indicates wide possibilities of crosses of $E$. deglupta with other species of sections in the subgenus Symphyomyrtus.

Being such a superbly adapted species to the humid equatorial climates, it is surprising to see plantations mainly confined to the Philippines, Papua-New Guinea and Solomon Islands. One reason may be its relative low wood density, but probably other areas where it can grow well, such as the vast Amazon area, Congo, Indonesia and Malaysia, did not test a wide range of provenances and did not consider the species because they tried only one or two provenances which happened to be unsuccessful. Some provenances are difficult to come by, such as Sulawesi, Seram and West Sepik, because 
seed collections were not made or not made available. Material from the Philippines, Papua-New Guinea and New Britain are easier to obtain. The resistance this species has to leaf blights, high humidity and temperatures are very advantageous (Davidson et al. 2018). Extraordinary hybrids have been produced earlier with considerable variation and increase in wood density (Glori 1993) and the ease to now do it through artificially induced protogyny, makes it extremely attractive for hybridization when plantations are considered for Af and Am climate zones.

\section{Eucalyptus tereticornis var. tereticornis}

E. tereticornis var. tereticornis, belonging to the section Exsertaria, series Exsertae, subseries Erythroxylon (Nicolle 2019), has a wide latitudinal range in Australia, on the east coast from southern NSW into Cape York Peninsula in Queensland (Boland et al. 2006). But it also occurs in PNG, where the most promising provenances for Af and Am climates occur. This tree is easy to reproduce from coppice shoots and hybridizes easily with other species of the sections Exsertaria, Latoangulata and Maidenaria. In Am climates the PNG provenances have been performing especially well (Morais, E.J., personal communication 2021). Being from medium-sized up to $50 \mathrm{~m}$ tall on favourable sites, it can tolerate several months of flooding as well (Boland et al. 2006). In plantations its wood can reach a better density than does E. urophylla or E. grandis, but it is quite susceptible to L. invasa. In spite of this susceptibility, vigorous individuals were found, growing well and not attacked by the gall wasp (Morais, E.J., personal communication, 2021) in an area of Am climate.

Especially if seed from PNG can be secured, it is a very good candidate for the Af and Am climates, both as a pure species and also as a hybrid partner. A breeding program for this species is important to be started in Af or Am climates, where it can withstand the high temperatures and high humidity.

\section{Eucalyptus brassiana}

E. brassiana is another representative of the section Exsertaria, series Exsertae, and subseries Subexsertae, therefore closely related to E. tereticornis var. tereticornis and also to E. camaldulensis. This species occurs in Queensland, on the north-eastern coast of Cape York Peninsula, on Horn Island and in PNG (Euclid - online edition, 2020). In plantations in Brazil in an Am/Aw climate adjoining the Amazon area and on poor soils, selected trees at 9 years had a density of $608-620 \mathrm{~kg} / \mathrm{m}^{3}$ (Morais, E.J., personal communication, 2021). An important feature of this species is that it withstands low fertility soils, although it will do better on fertile soils. Hybrids have been formed with E. pellita (probably E. biterranea) in Indonesia and Brazil, and these have the excellent form of E. pellita, with a lower bark percentage, better growth and the high wood density inherited from both species. Apparently no tree improvement program has focused specifically on E. brassiana as yet. However, for the Af, Am and Aw climates it is well suited and should be one of the partners considered for hybridization for Af climate, due to the high wood density and to its adaptation to equatorial conditions. The best provenances for equatorial climates originate in PNG.

\section{Eucalyptus leptophleba}

This species is in Symphyomyrtus, section Adnataria, series Striolatae (Nicolle 2019). No literature about this species as a plantation species has been found. Boland et al. (2006) describe its occurrence on Cape York Peninsula, extending into western PNG. It has very dense wood in natural populations. It is a medium sized tree up to $25 \mathrm{~m}$. It does have a good adaptation to hot and humid climates, and probably the PNG provenances, if they can be obtained, would prove best for Af and Am climates. It is worthwhile to be tried in equatorial climates, due to its natural occurrence.

Since it belongs into the section Adnataria, it is questionable if it could be used as hybrid partner with species in the sections Maidenaria, Latoangulata and Exsertaria. E. paniculata, which also belongs into the section Adnataria, is not known to easily produce hybrids with species of the above three sections. However, it must be tried. If E. leptophleba proves to be a good plantation species for equatorial climates, breeding programs with it must be started and hybridization trials as well.

\section{Eucalyptus urophylla}

This is another of only a handful of extra-Australian eucalypts and it occurs on eight of the Lesser Sunda Islands of Indonesia and East Timor, usually from 500-2000 m asl, precipitation ranging from 600-2500 mm, with a dry season of 4-6 months (Dvorak et al. 2018). Due to the dry season and altitude in its native range, it will probably not be adaptable to Af climates, even though some provenances might prove better adapted than others. It can be used mainly as a hybrid partner, both for the Af and also Am climates, possibly with E. pellita or E. deglupta participating in the hybridization as a single partner or in 3-way and 4-way crosses. It definitely deserves wide testing for equatorial climates, but it is susceptible to leaf blights in hot and warm environments. Since such areas are different from the higher altitude areas of natural occurrence, the species as a whole may not be adapted. However, breeding and especially hybridization will select and inject the genes from other species to overcome this climate incompatibility. E. urophylla is one of the main species for hybridization in the subtropical world; over $80 \%$ of the hybrids in Brazil contain some E. urophylla in them (Assis 2015) and it is also used as a pure species. There are several breeding programs with it. It hybridizes easily with many species, also with E. grandis, E. saligna, and several in the Exsertaria and Maidenaria section and very frequently results in heterosis when hybrids are produced. Therefore, it must be considered one of the priority species for eucalypt breeding in equatorial climates. The many crosses already using E. urophylla enrich the gene pool to be tried closer to the equator. 


\section{Other species for hybridization}

The exclusively extra-Australian and much smaller species $E$. alba var. alba, E. orophila and E. wetarensis might be tried for hybridization also as they come from hot lowland climates. While E. orophila and E. wetarensis are very close to E. urophylla belonging into the section Latoangulata series Robustae, $E$. alba var. alba belongs into the section Exsertaria and could possibly contribute genes for deep roots and quick establishment in areas of low fertility, as presumably E. brassiana, E. tereticornis var. tereticornis and E. camaldulensis from Exsertaria would. However, the small size of these species relegates them to a secondary level for hybridization.

While E. grandis and E. saligna are not appropriate for equatorial climates, they do have growth and wood characteristics which make them attractive for hybridization into the species adapted to those climates. Similarly, E. longirostrata and $E$. punctata could also add genes of interest.

In the section Transversaria there is E. camaldulensis. This species has the widest spread of any species over Australia and has been subdivided into seven subspecies by McDonald et al. (2009). Among the north Australian subspecies which are more adapted to hot environments are E. camaldulensis ssp. acuta, ssp. obutsa and ssp. simulata. The species has been domesticated widely and there are good seed sources available for trials. It is quite susceptible to the L. invasa gall wasp, but with a wide variation of resistance among the subspecies, provenances and individuals. In West Africa, in the subspecies obtusa from Katherine River, NT, Australia, only $5 \%$ of the individuals in plantation were attacked. E. camaldulensis is remarkable in that it is usually associated to river banks and thus called River Red Gum, and can tolerate several months of flooding (Water for a Healthy Country 2004). Seedlings of E. camaldulensis can produce aerenchymatous roots under flooding (Water for a Healthy Country 2004).

Outside Australia this species is generally associated with drought tolerance, and establishes in poor soil by quickly developing a deep tap root. Root development is often not understood. Christina et al. (2011) found that in deep soils E. grandis deep root development was $85 \%$ of above soil growth until roots reached the water table. In E. camaldulensis it would probably be quicker and deeper. In Ghana E. camaldulensis grows continually throughout the 5-6 months of the dry period. While the pure species will most probably not survive or flower in hot and humid environments, as a hybrid partner it may impart the quick establishment, growth and adaptability to poor soils, which probably was the case in the E. deglupta $x$ E. camaldulensis hybrid K7 in Southeast Asia in the 1990's and 2000's (Ito 2009). Many equatorial regions present heavy waterlogging in part of the year and often have poor, leached soils, for which the genes contributed by E. camaldulensis and other species from the Exsertaria section could be very helpful in overcoming. The hypoxia which comes with flooding or compacted soils is detrimental to most trees, which switch from respiration to fermentative processes and glycolysis in order to survive (Kreuzwieser et al. 2014, Liu et al. 2015). Compacted, hypoxic soils lead to splitting of the bark and stunted growth with consequent invasion by fungi and bacteria in equatorial climates
(Rosa, A., personal communication, 2020). E. camaldulensis and other Exsertaria species' genes (e. g. E. brassiana and E. tereticornis var. tereticornis) could help alleviate this problem when introduced into species well adapted to the climate but not to poor, compact or drenched soil conditions. Most eucalypt species demand deep drained soils with at least moderate fertility, but several Exsertaria species thrive in poor, compacted, dry or waterlogged soils.

There are many more possibilities available for hybridizing for equatorial climates. Within the section Maidenaria are most of the species used for cold hardiness (E. globulus, E. maidenii, $E$. bicostata, E. nitens, E. dunnii, E. viminalis, E. macarthurii, E. smithii, E. benthamii, E. badjensis and more). Several of these carry genes for high quality wood for use in the cellulose industry. Since many of these, when crossed with E. urophylla (very tropical) yielded heterotic hybrids with increased wood quality for pulp and adaptability to the tropics, it might be of much interest to also cross them with the highly adapted equatorial species, such as E. pellita and E. deglupta, in order to obtain adapted hybrids with quality wood for the cellulose industry.

Since much hybridization has already produced very productive hybrids in the subtropical regions, these same hybrids are a good starting point to introduce into the species adapted to the equatorial climate.

\section{Dangers associated with short rotation planta- tions of Eucalyptus species and hybrids in the equatorial regions}

There are dangers associated with short-rotation eucalypt plantations. All of them are susceptible to suddenly appearing or adapting pests and diseases. Many insects may appear suddenly due to accidental introductions. The adaptation of Ceratocystis manginecans to Acacia mangium detected in Southeast Asia (Tarigan et al. 2011) in this century is threatening all the widely planted $A$. mangium plantations. This disease also attacks the occasional $E$. biterranea tree. It may remain in the soil for many years in the form of aleuroconidia (Nasution 2019). Ganoderma philippii similarly is attacking A. mangium and the incidence increases in each rotation (Page et al. 2020). These diseases until now have been impossible to control by biological means (Nambiar et al. 2018). The spread of the Australian gall wasp L. invasa was first detected in Israel in 2000 and quickly spread all over the world, showing up in Brazil in 2008 (Silva 2019). The very successful hybrid, K7, of E. camaldulensis $x$ E. deglupta in Thailand, Laos and Vietnam (Ito 2009), later was abandoned due to its susceptibility to L. invasa. Thaumastocoris peregrinus, Ophelimus gaskelli, Glycapsis brimblecombei and the Gonipterus spp. complex appeared in the last decades in Brazil (Silva 2019) and several continents and countries.

The other threat from short-rotation eucalypt plantations is that they may deplete the soil of vital nutrients if not managed carefully (Harwood 1998, Harwood and Nambiar 2014b), especially during the inter-rotational period. Eucalypts demand soils of moderate to high fertility (Harwood 1998). Since eucalypts do not fix nitrogen as acacias do, additional nutrients have to be supplied externally by supplemental fertilization. 
Both problems can be solved. Short rotation plantation trees associated to an active breeding program aiming at constantly producing new hybrids, and the concomitant planting and testing of different clones is a good strategy to stay ahead of susceptibilities and new surges of pests and diseases. Such strategies have been very successful in Brazil and South Africa. Fertility problems can be alleviated by leaving bark and residues of harvesting in the field and by appropriate fertilization schemes. The mixed planting of A. mangium and Eucalyptus was positive in Congo in an Am climate, leading to more overall above-ground production, but not on an Aw site in Brazil, where water may have been the limiting factor (Epron et al. 2013). In Brazil and South Africa in spite of new pests and diseases appearing, productivity of eucalypt plantations has constantly increased over the last 40 years (Harwood and Nambiar 2014a). In Brazil productivity of $25-30 \mathrm{~m}^{3} /$ ha/year last century, is in the range of $35-45 \mathrm{~m}^{3} /$ ha/year now, exceeding $60 \mathrm{~m}^{3} / \mathrm{ha} /$ year occasionally (Rezende et al. 2014) while many new pests appeared. This progress was achieved by changing and diversifying to more productive and resistant hybrids and clones and by continuously optimizing forest management.

\section{Corymbia}

Another genus in the eucalypts with planting possibilities in Af climates is Corymbia. This genus comprises only two subgenera (Corymbia and Blakella) and approximately 95 species and several subspecies (Nicolle and Jones, 2018).

According to Nicolle (2019) the classification of the here mentioned taxa is represented in Table 5. (possibly C. clarksoniana), C. latifolia, C. tessellaris, C. papuana and $C$. disjuncta. Hence this genus is also well represented in hot, humid environments (Af and Am). Moreover, in the extreme north and humid North Territory and York Peninsula, potential species for adaptation to Af climate occur, such as C. intermedia, C. bleeseri, C. trachyphoia, C. nesophila and C. clarksoniana. Corymbia, as Eucalyptus, offers wide possibilities of hybridization. Differently from Eucalyptus, the two Corymbia subgenera often produce hybrids when crossed.

Several species within this genus attain sizable growth, as is the case of C. polycarpa, C. clarksoniana, C. intermedia, C. nesophila, C. torelliana, C. citriodora, C. variegata, C. maculata and C. henryi (Boland et al. 2006). Other tropical species attaining about $15 \mathrm{~m}$ in their natural environments include: $C$. tessellaris, C. confertiflora, C. ptychocarpa, C. bleeseri, C. erythrophloia, C. trachyphloia, C. peltata and C. leichhardtii. There is as yet little experience with many of these species in plantation or as hybrid partners. This is an area of extraordinary possibilities and research.

C. torelliana comes from a humid, high rainfall $(800-2,500$ $\mathrm{mm} /$ year) Am climate, with a summer maximum of rain (Boland et al. 2006). The species has a wide adaptation potential, having been successfully planted in areas with up to 40 frosts/year and dry areas with only $400 \mathrm{~mm}$ of rain in Australia. It can be rooted from coppice shoots with relative ease (Resende et al., 2014; Rezende et al. 2014). It has been crossed more often with C. citriodora, C. variegata and C. henryi (Resende et al. 2014), but also with several other species of the genus (Dickinson et al. 2007). Successful plantation hybrids have been established in many places in Brazil, South Africa, Australia, and more.

Table 5

Classification of some of the most important species in the subgenus Corymbia

\begin{tabular}{|c|c|c|c|c|c|}
\hline Genus & Subgenus & Section & Series & Subseries & species \\
\hline Corymbia & Corymbia & Corymbia & Trachyphloiae & & trachyphloia \\
\hline “ & “ & “ & Dorsiventrales & & ptychocarpa \\
\hline “ & “ & “ & Dorsiventrales & & polycarpa \\
\hline “ & “ & “ & Dorsiventrales & & clarksoniana \\
\hline " & “ & “ & Dorsiventrales & & intermedia \\
\hline “ & “ & " & Isobilaterales & Peltiformes & nesophila \\
\hline “ & “ & “ & Isobilaterales & “ & bleeseri \\
\hline “ & “ & “ & Isobilaterales & Limitaneae & erythrophloia \\
\hline “ & Blakella & Naviculares & & & peltata \\
\hline “ & “ & “ & & & leichhardtii \\
\hline " & “ & Torellianae & & & torelliana \\
\hline “ & “ & Maculatae & & & citriodora \\
\hline “ & “ & “ & & & variegata \\
\hline “ & “ & “ & & & maculata \\
\hline “ & “ & “ & & & henryi \\
\hline " & “ & Abbreviatae & Tessellatae & & tessellaris \\
\hline " & " & " & “ & & confertiflora \\
\hline
\end{tabular}

There is not a single exclusively extra-Australian species, but there are approximately five occurring in Australia and PapuaNew Guinea or Indonesia (Nicolle 2019): C. novoguinensis
It is remarkable that it is possible to hybridize widely among the two subgenera Blakella and Corymbia (Dickinson 2007). Most of the possible hybrids, even of the taller species have not been tried yet. 
The wide adaptability seems to be general in several Corymbia species. Thus, C. citriodora, coming from a typical summer rainfall area in Southeast Queensland and Northeast New South Wales, has been successfully established in the winter rainfall area (Mediterranean climate) in Perth, where beautiful mature trees of it line some streets. This adaptation from $\mathrm{Cw}$ climate warm temperate with dry winter (Cw) to warm temperate with dry summer (Cs) is an amazing potential, not found in most species in the genus Eucalyptus. Thus it is not surprising to find the hybrid $C$. torelliana $\times C$. citriodora being established successfully in a wide variety of climates in Brazil, Venezuela, Honduras, West Africa and Australia in Am and Aw climates. There is anecdotal information of some of this hybrid now successfully growing in Kalimantan, Indonesia, Af climate. The ease of cloning C. torelliana is passed on to some of the hybrids with C. citriodora (Assis 2015). The typical wood density of over $600 \mathrm{~kg} / \mathrm{m}^{3}$ makes these widely adaptable species and hybrids attractive for plantations not only for solid wood, energy, pulp (Resende et al. 2014) as well as for their adaptability (Dickinson et al. 2007, Lee et al. 2009, Pegg et al. 2013, Resende et al. 2014, Rezende et al. 2014). The hybrid C. torelliana $\times$ C. henryi grows successfully in South Africa, Brazil and tropical West Africa and is plastic in its adaptation. C. henryi originates from north-eastern N. S. Wales and south-eastern Queensland, while C. torelliana comes from north-eastern Queensland (Boland et al. 2006).

Among the medium-sized tropical Corymbia species there are: C. tessellaris, C. confertiflora, C. ptychocarpa, C. bleeseri, C. erythrophloia, C. trachyphloia, C. peltata and C. leichhardtii (Boland et al. 2006). Very few of them have been tried in hybridization as yet, but some have been hybridized with C. torelliana (Dickinson et al. 2007), both in the subgenus Corymbia as in the subgenus Blakella, which attests to the wide range of hybridization possibilities.

Of the above species, hybridization is likely to be mainly confined for some time to C. torelliana (subgenus Blakella, section Torellianae) and the spotted gums (subgenus Blakella, section Maculatae: C. citriodora, C. variegata, C. henryi and C. maculata), due to their genetic affinity, the timber value of the species and hybrids, the wide introduction of these species abroad and difficulty to obtain pollen in other countries than Australia. Even in the native habitat in Australia, many years may pass without flowering of some species. Grafting, air-layering and the use of flowering enhancing paclobutrazole helps in countries without natural flowering.

For extreme tropical conditions (Af and Am climates), it will be much advantageous if species attaining high growth, like $C$. intermedia and $C$. nesophila be tried, as species and especially as hybrid partners. Dickinson et al. (2007) obtained best seed set when crossing $C$. torelliana with the closely related $C$. citriodora, C. variegata and C. henryi, but less when crossed to the also closely related $C$. maculata, all within the subgenus Blakella. When crossing $C$. torelliana they obtained reasonable seed set from the crosses with C. erythrophloia, C. intermedia and $C$. clarksoniana. This shows again the wide hybridization potential within the genus Corymbia. The wide crossability allied to heterosis and the plasticity of most hybrids, renders them very attractive for hybridization and planting in tropical environments.

The species C. ptychocarpa - swamp bloodwood from Northwest Australia and North Australia, usually growing in wet sites along river banks (Boland et al. 2006) has large red filaments and has been grown in suitable sites for amenity. It has been hybridized in Australia with C. ficifolia, a small redflowered species from Western Australia and winter rainfall regions and poor adaptation to summer rain areas, producing many clones for ornamental purposes with a wide adaptability in Australia. Several clones of this hybrid are available for sale from garden enterprises. There is obviously an extraordinary adaptability of the hybrids within this genus. C. ptychocarpa is not a large species, but planted in small plots in West Africa was successful and had good growth in the first four years.

Queensland and New South Wales developed a breeding program with the pure species of the spotted gums (C. citriodora, C. variegata, C. henryi and C. maculata) and hybrids with $C$. torelliana, used as the maternal or seed parent (Lee 2007). Using $C$. torelliana as seed parent assures a much better rooting of clones than when using C. citriodora, C. henryi and $C$. maculata as seed parent (Assis 2015), as seen in the Table 6. Rooting percentage was double on average, when using $C$. torelliana as seed parent as compared to when using it as pollen donor. Ability to root seems to have a strong maternal component.

\section{Table 6}

Rooting percentage of clones from C. torelliana as seed parent or C. citriodora as seed parent (from Assis, 2015)

\begin{tabular}{llc}
\hline Clone & \multicolumn{1}{c}{ Hybrid } & Rooting \% \\
\hline$M-1$ & C. citriodora $\times$ C. torelliana & 16.41 \\
$M-4$ & C. torelliana $\times$ C. citriodora & 41.91 \\
$M-7$ & C. torelliana $\times$ C. citriodora & 43.60 \\
$M-22$ & C. citriodora $\times$ C. torelliana & 33.57 \\
$M-43$ & C. torelliana $\times$ C. citriodora & 39.34 \\
$M-44$ & C. citriodora $\times$ C. torelliana & 13.56 \\
\hline
\end{tabular}

Rooting is further dramatically enhanced, when using shoots originating from the lignotuber region of the trees (Assis 2015), both in seedlings as well as in adult trees, even in pure C. citriodora trees, which is considered to be very difficult to root by conventional means as used in Eucalyptus. Another technique to obtain higher rooting percentages from shoots is by the use of low-ceiling hermetically closed plastic tunnels to keep mother plants (Assis 2015). The morphology of the leaves in the tunnel changes, becoming a bit lighter and narrow. Techniques such as inducing shoots from lignotuber regions and the use of mini-tunnels improve dramatically the rooting percentage, also in other difficult-to-root eucalypt species. Programs of hybridization such as the above, mainly with C. torelliana and the spotted gums are ongoing in Brazil, Australia, Venezuela, Honduras and South Africa and possibly in other parts of the world as well. The plasticity of the hybrids exhibiting hererosis is very promising. 
Table 7

Wood densities from some hybrid clones at age 5 and 7 and MAl over bark at age 7 (from Assis, 2015)

\begin{tabular}{|c|c|c|c|}
\hline Clones & Density at 5 years $\left(\mathrm{kg} / \mathrm{m}^{3}\right)$ & Density at 7 years $\left(\mathrm{kg} / \mathrm{m}^{3}\right)$ & $\operatorname{MAl}\left(\mathrm{m}^{3} / \mathrm{ha} / \mathrm{yr}\right)$ \\
\hline M-01 - C. citriodora $\times$ C. torelliana & 516 & 694 & 47.60 \\
\hline M-03 - C. torelliana $\times$ C. citriodora & 518 & 569 & 42.64 \\
\hline M-04 - C. torelliana $\times$ C. citriodora & 633 & 702 & 24.09 \\
\hline M-07 - C. torelliana $\times$ C. citriodora & 572 & 660 & 49.88 \\
\hline M-22 - C. citriodora $\times$ C. torelliana & 529 & 544 & 41.12 \\
\hline M-43 - C. citriodora $\times$ C. torelliana & 612 & 628 & 42.31 \\
\hline
\end{tabular}

Characteristics such as high wood density, makes these hybrids attractive for solid wood production but also suitable for paper. Table 7 attests to the fact that some hybrids not only result in high wood density (usually higher than $600 \mathrm{~kg} / \mathrm{m}^{3}$ ), but also considerable MAl above bark, as found in Brazil, Rio Doce Valley. Most of the wood properties are inherited in additive manner so that hybrids tend to be intermediate between parents for such characteristics. The interesting fact is also that most hybrids are plastic and perform well in very different environments, displaying low genotype x environment variation.

The hybrids of $C$. torelliana $\times C$. citriodora may exhibit a high bark percentage, varying from 8-30\% of the total wood (Assis, personal information 2021), but with a wide variation to select from.

Corymbia species are not immune to diseases, with Puccinia psidii (Pegg et al. 2013) and Quambalaria pitereka -being two of them, but with some tolerance and even resistance in several hybrids with $C$. torelliana as one of the parent (Lee 2007). Kino pockets often are formed when some species like C. citriodora are exposed to physical stress. Kino pockets and veins are detrimental when using the trunks for solid wood or for pulp. Kino seems not to occur in the hybrid with C. torelliana. In Rio Doce Valley in Brazil, there is a problem with many eucalypts, also C. citriodora, which appears in dry winters, with rolling of leaves and tip drying, from a not yet clearly defined origin and often called "tip-drying or physiological disturbance of Rio Doce Valley". C. torelliana does not exhibit this problem and neither does the hybrid with C. citriodora.

The pure species spotted gums were strongly attacked by Quambalaria pitereka leaf blight in the programs which in the 1990 's led to a practical abandonment of these valuable timber species for plantations in Queensland, until tolerant provenances were found, except in C. henryi. C. torelliana was not Quambalaria susceptible and hence was used as a parent for hybridization, being also amenable to vegetative propagation by coppice shoots, as are its hybrids with all the spotted gums (Lee 2007). Frost resistance in the hybrids was similar to the spotted gum species. Many hybrid families displayed heterosis with better height and diameter growth, straightness, Quambalaria tolerance, erinose mite tolerance and better coppice rooting ability than the pure species. The families were stable across many sites (Lee 2007).

The above facts show that many hybrid Corymbia are very promising for productivity, resistance to diseases, are amenable to rooting from coppice shoots, plastic in their adaptability to varied environments where they have been tested. However, there are diseases and insects which can attack either parent or hybrids. C. torelliana has been attacked by defoliating beetles in some places in Brazil and on Borneo, especially on seedlings. In West Africa, grasshoppers preferentially foraged on $C$. citriodora and C. torelliana $\times$ C. citriodra hybrids, but neglected pure $C$. torelliana.

Most hybridization has taken place using C. torelliana as maternal parent, and the spotted gums as paternal parent. The hardly explored hybrid possibility using other species still remains open. For Af climates, the uses of $C$. torelliana, $C$. nesophila, C. polycarpa, C. clarksoniana, C. intermedia, C. tessellaris, C. confertiflora, C. ptychocarpa, C. bleeseri, C. erythrophloia, C. trachyphloia, C. peltata and C. leichhardtii and again the spotted gums as species but especially as hybrid parents offers many possibilities, but also in Am climate. Diseases and insect attacks are to be expected in those hot, humid environments, but the many hybridization potentials seem to be able to overcome these difficulties, as is being shown in Brazil, South Africa and elsewhere in the genus Eucalyptus.

\section{Conclusion}

High forest productivity can be obtained in the hot, humid, equatorial Af climate zones; high rainfall all year round helps to attain it. By breeding with adapted Eucalyptus species and those tolerant of temporary flooded and poor soils such as E. biterranea, E. deglupta, E. tereticornis var. tereticornis, E. brassiana, and species successful in subtropical areas, such as E. urophylla, E. grandis, E. camaldulensis, Brazil and Indonesia have produced successful hybrid clones. Furthermore, in the genus Corymbia the chances stand equally high, if $C$. torelliana, C. citriodora, $C$. variegata, $C$. henryi and $C$. maculata and their hybrids are used. In addition, species which should be tried pure and as hybrid partners include $C$. nesophila, C. polycarpa, C. clarksoniana, $C$. intermedia, C. tessellaris, C. confertiflora, C. ptychocarpa, C. bleeseri, C. erythrophloia, C. trachyphloia, C. peltata and C. leichhardtii. Short rotation forestry with many hybrid combinations and vegetative propagation help avoid and evade disease surges by quickly replacing existing clones by new ones and by maintaining plantations with a wide composition of different genotypes in the clones. At the same time, clonal short-rotation 
forestry is a challenge for management in order to avoid nutrient depletion of soils, which can be overcome by careful nutrient and fertilization schemes, also by mixing into the plantation nitrogen-fixing species or rotating with these and by leaving foliage and bark in the field at harvest.

\section{Acknowledgements}

I thank David B. James and Teotonio F. de Assis for their critical review and an anonymous reviewer for several improvements in the text.

\section{References}

Álvares CA, Stape JL, Gonçalves JLM (2011) Mapping of the Brazil Eucalyptus Pontential Productivity. In: IUFRO Working Group 2.08.03 - Improvement and Culture of Eucalyptus. 2011: Porto Seguro, Bahia State, Brazil. Proceedings, Piracicaba. (2) 156-159.

Arsensi I, Lahjie AM, Simarangkir BDAS, Mardji D (2016) Leaf Diseases on Eucalyuptus pellita F. Muell in Plantation of Pt Surya Hutani Jaya at Sebulu, East Kalimantan. Intl. J. of Scientific \& Technology Res. 5, 12: 10-15.

Assis TF (2000) Production and use of Eucalyptus hybrids for industrial purposes. In "Hybrid Breeding and Genetics of Forest Trees" Proceedings QFRI/CRCSPF Symposium, 9-14 April 2000, Noosa, Queensland, Australia. (Compiled by Dungey, H.S., Dieters, M.J. and Nikles, D.G.), Department of Primary Industries, Brisbane.

Assis TF, Fett-Neto AG, Alfenas AC (2004) Current techniques and prospects for the clonal propagation of hardwoods with emphasis on Eucalyptus. In: Plantation Forest Biotechnology for the 21st Century: 303-333.

Assis TF, Warburton P, Harwood CE (2005) Artificially induced protogyny: an advance in the controlled pollination of Eucalyptus. Australian Forestry 68: 27 33. https://doi.org/10.1080/00049158.2005.10676223

Assis TF, Abad JIM, Aguiar A (2015) Melhoramento Genético do Eucalipto. In: Schumacher MV, Vieira M (eds.) Silvicultura do Eucalipto no Brasil, Capítulo 7: 225-247 Ed. UFSM, Santa Maria, Brazil.

Assis TF (2006) Os propulsores da produtividade dos eucaliptos. Revista Opiniões, p. 14, nov-fev. 2006.

Assis TF (2011) Hybrids and Mini-Cuttings: A Powerful Combination that has revolutionized the Eucalyptus Clonal Forestry. BMC Proceedings, v.5, (Suppl. 7) https://doi.org/10.1186/1753-6561-5-s7-i18

Assis TF (2014) Melhoramento genético de Eucalyptus: desafios e perspectivas. In: SIMPÓSIO BRASILEIRO DE SILVICULTURA, 3, 2014, Campinas. Anais Curitiba: EMBRAPA-CNPF, 2014, 1; 127-148.

Behling M, Piketty MG, Morello TF, Bouillet J-P, Mesquita Neto F, Laclau J-P (2011) Plantations d'eucalyptus et sidérurgie en Amazonie: apports du modèle 3-PG. Bois et Forêts des Tropiques 309 (3) 37-49. https://doi.org/10.19182/bft2011.309.a20464

Boland DJ, Brooker MIH, Chippendale GM, Hall N, Hyland BPM, Johnson RD, Kleinig DA, McDonald MW, Turner JD (2006) Forest Trees of Australia, 5th Ed. CSIRO Publishing. https://doi.org/10.1071/9780643069701

Buongiorno J, Zhu S (2014) Assessing the impact of planted forests on the global forest economy. New Zealand Journal of Forestry Science, 44 (Suppl 1): S2. https://doi.org/10.1186/1179-5395-44-s1-s2

Chaplin G (1993) Silvicultural Manual for the Solomon Islands. Solomon Islands Forest Record N6. ODA Forestry Series $N^{\circ} 1,305 \mathrm{pp}$. https://doi.org/10.1515/9783112422144-168

Christina M, Laclau J-P, Gonçalves JLM, Jourdan C, Nouvellon Y, Bouillet J-P (2011) Almost symmetrical growth rates above and below ground in one of the world's most productive forests. Ecosphere 2(3), article 27 https://doi.org/10.1890/es10-00158.1
Cossalter C (1975) Location and Ecological Data of Some Provenances of Eucalyptus deglupta Blume in the Celebes and Ceram Islands - Characteristics of the Natural Stands. Forest Genetic Information $N^{\circ} 6$ www.fao.org/3/k4063e/ K4063E03.htm

Davidson J, Gunn B, Spencer D (2018) Eucalyptus deglupta pp 104-107, in: Thomson L, J Doran and B Clarke (eds.) 2018. Trees for Life in Oceania: conservation and utilization of genetic diversity. ACIAR Monograph No. 201. Australian Centre for International Agricultural Research: Canberra. 278 pp.

Dickinson GR, Wallace HM, Kelly NI, Lee DJ (2007) Interspecific Corymbia hybrid research; providing new opportunities for plantation expansion in northern Australia. Researchgate.net/publication/242409709.

Dvorak B, Doran J, Rimbawanto A ( ） Eucalyptus urophylla (including E. wetarensis and E. orophila) pp 112-115, in: Thomson L, J Doran and B Clarke (eds.) 2018. Trees for Life in Oceania: conservation and utilization of genetic diversity. ACIAR Monograph No. 201. Australian Centre for International Agricultural Research: Canberra. 278 pp.

Elias P, Boucher D (2014) Planting for the Future - How Demand for Wood Products Could Be Friendly to Tropical Forests. Union of Concerned Scientists. 29 pp www.ucsusa.org/forests

Elli EF, Huth N, Sentelhas PC, Carneiro RL, Álvares CA (2020) Global sensitivity-based modelling approach to identify suitable Eucalyptus traits for adaptation to climate variability and change. In Silico Plants 2020. https://doi.org/10.1093/insilicoplants/diaa003

Epron D, Nouvellon Y, Mareschal L, Moreira RM, Koutika L-S, Geneste B, Delgado-Rojas JS, Laclau J-P, Sola G, Gonçalves JLM, Bouillet J-P (2013) Partitioning of net primary production in Eucalyptus and Acacia stands and in mixed-species plantations: Two case-studies in contrasting tropical environments. Forest Ecology and Management 301 (2013) 102-111. https://doi.org/10.1016/j.foreco.2012.10.034

Eucalyptus brassiana, Cape York red gum, Gum-topped peppermint, Karo (Papua-New Guinea) Euclid- Online edition. https://apps.lucidcentral.org/euclid

Evans J Ed. (2009) Planted Forests - Uses, Impacts and Sustainability. Publ. FAO\& CABI, $213 \mathrm{pp}$

FAO and UNEP (2020) The State of the World's Forests 2020. Forests, biodiversity and people. Rome. htpps://doi.org/10.4060/ca8642en

Glori A (1993) The eucalyptus tree improvement programme of PICOP. Regional Symposium in mass clonal multiplication of Forest Trees for Plantation Programmes. Proc. of the symposium held 1-3 December 1992 in Cisarua, Bogor, Indonesia (Ed.: John Davidson). UNDP/FAO Regional Project on Improved Productivity of man-made forests through the application of 'Technological Advances' in Tree Breeding and Propagation (FORTIP) Field Document $N^{\circ} 4$ RAS/91/004. Food and Agriculture Organization of the United Nations. Los Baños, Philippines, March 1993. 254-261.

Gonçalves JLM, Álvares CA, Higa AR, Silva LD, Alfenas AC, Stahl J, Ferraz SFD, Lima WP, Brancalion PHS, Hubner A, Bouillet J-PD, Laclau J-P, Nouvellon Y, Epron D (2013) Integrating genetic and silvicultural strategies to minimize abiotic and biotic constraints in Brazilian eucalypt plantations. Forest Ecology and Management. http://dx.doi.org/10.1016/j.foreco.2012.12.030

Gustafson EJ, Miranda BR, de Bruijn AMG, Sturtevant BR, Kubiske ME (2017) Do rising temperatures always increase forest productivity? Interacting effects of temperature, precipitation, cloudiness and soil texture on tree species growth and competition. Environmental Modelling \& Software 97: 171-183.

Harwood CE (1998) Potential Exotic Species for Establishing Planted Forests. In: Proceedings of Planted Forests in Sarawak - An International Conference, 16-18 February 1998, Kuching, Sarawak, Malaysia 82-99.

Harwood CE (2011) New Introductions - Doing it Right. Pp. 43-54 in Walker, J. (ed.) Developing a eucalypt resource: learning from Australia and elsewhere. (Wood Technology Research Centre: Christchurch)

Harwood CE (2018) Eucalyptus pellita pp 108-111, in: Thomson L, J Doran and B Clarke (eds.) 2018. Trees for Life in Oceania: conservation and utilization of genetic diversity. ACIAR Monograph No. 201. Australian Centre for International Agricultural Research: Canberra, 278 pp.

Harwood CE, Nambiar EKS (2014a) Sustainable plantation forestry in South-East Asia. ACIAR Technical Reports No. 84. Australian Centre for International Ag ricultural Research: Canberra, $100 \mathrm{pp}$.

Harwood CE, Nambiar EKS (2014b) Productivity of acacia and eucalypt plantations in Southeast Asia. 2. Trends and Variations. Intl. For. Review 16 (2): 249 260. https://doi.org/10.1505/146554814811724766 
Hill KD, Johnson LAS (2000) Systematic Studies in the Eucalypts. 10. New tropical and subtropical eucalypts from Australia and New Guinea (Eucalyptus, Myrtaceae). Telopea 8(4): 503-540. https://doi.org/10.7751/telopea20002007

House APN, Bell JC (1996) Genetic diversity, mating systems and systematic relationships in the two red mahoganies, Eucalyptus pellita and E. scias. Australian Journal of Botany 44: 157-174. https://doi.org/10.1071/bt9960157

IBÁ (2020) Indústria Brasileira de Árvores, Relatório Anual (Brazilian Tree Industry, Annual Report) $122 \mathrm{pp}$.

Ito K (2009) Hardwood Plantation Project for Pulpwood in Laos. In: Workshop: Understanding the Contemporary Environmental and Livelihood Connections in Mainland Southeast Asia. Power point: ercsd.env.nagoya-u.ac.jp/envgcoe/ito. pdf

Japarudin Y, Lapammu M, Alwi A, Warburton P, Macdonnell P, Boden D, Brawner J, Brown M, Meder R (2020) Growth performance of selected taxa as candidate species for productive tree plantations in Borneo, Australian Forestry. https:// doi.org/10.1080/00049158.2020.1727181

Kottek M, Grieser J, Beck C, Rudolf B, Rubel F (2006) World Map of the Köppen-Geiger climate classification updated. Meteorologische Zeitschrift, Vol 15, No 3 , 259-263.

Kreuzwieser J, Rennenberg H (2014) Molecular and Physiological Responses of Trees to Waterlogging Stress. Plant, Cell and Environment 37: 2245-2259. https://doi.org/10.1111/pce.12310

Ladiges PY (1997) Phylogenetic History and Classification of Eucalypts. Chapter 2 in Williams JE and JCZ Woinarski (eds), Eucalypt Ecology, Cambridge University Press, Cambridge pp.16-29.

Lee DJ (2007) Achievements in forest tree genetic improvement in Australia and New Zealand 2: Development of Corymbia species and hybrids for plantations in eastern Australia. Australian Forestry, 2007, v. 70 No 1 pp. 11-16. https://doi.org/10.1080/00049158.2007.10676256

Lee DJ, Huth JR, Brawner JT, Dickinson GR (2009) Comparative Performance of Corymbia Hybrids and Parental Species in Subtropical Queensland and Implications for Breeding and Deployment. Silvae Genetica 58-5/6, 205-212. https://doi.org/10.1515/sg-2009-0026

Liu B, Rennenberg H, Kreuzwieser J (2015) Hypoxia Affects Nitrogen Uptake and Distribution in Young Poplar (Populus $x$ canescens) Trees. PLoS ONE 10 (8): e0136579. https://doi.org/10.1371/journal.pone.0136579

Majer JD, Recher HF (1999) Are eucalypts Brazil's friend of foe? An entomological viewpoint. An. Soc. Entomol. Bras. 28, No 2 pp. 10

McDonald MW, Brooker MIH, Butcher PA (2009) A taxonomic revision of Eucalyptus camaldulensis (Myrtaceae). Australian Systematic Botany, 22, 257-285. https://doi.org/10.1071/sb09005

Nambiar EKS, Harwood CE, Mendham DS (2018) Paths to sustainable wood supply to the pulp and paper industry in Indonesia after diseases have forced a change of species from acacia to eucalypts. Australian Forestry. htpps://doi.org/10.1080/000491158.2018.1482798

Nasution A, Glen M, Beadle C, Mohammed C (2019) Ceratocystis wilt and canker a disease that compromises the growing of commercial Acacia-based plantations in the tropics. Australian Forestry, 82: supp 1, 80-93. https://doi.org/10.1080/00049158.2019.1595347

Nicolle D, Jones RC (2018) A revised classification for the predominantly eastern Australian Eucalyptus subgenus Symphyomyrtus sections Maidenaria, Exsertaria, Latoangulatae and related smaller sections (Myrtaceae). Telopea, v. 21:129145. https://doi.org/10.7751/telopea12571

Nicolle D (2019) Classification of the Eucalypts (Angophora, Corymbia and Eucalyptus) Version 4. http://www.dn.com.au/Classification-Of-The-Eucalypts.pdf

Organization for Economic Co-operation and Development (OECD) (2014). Environment, Health and Safety Publication, Series on Harmonization of Regulatory Oversight in Biotechnology No. 58, 81 pp. Consensus Document on the Biology of Eucalyptus spp.

Page D, Glen M, Puspitasari D, Gafur A, Mohammed C (2020) Acacia Plantations in Indonesia facilitate clonal spread of the root pathogen Ganoderma philippii. Plant Pathology Vol. 69, Issue 4, 685-697. https://doi.org/10.1111/ppa.13153

Payn T, Carnus J-M, Freer-Smith P, Kimberley M, Kollert W, Liu SR, Orazio C, Rodriguez L, Silva LN, Wingfield MJ (2015) Changes in planted forests and future global implications. Forest Ecology and Management 352: 57-67. https://doi.org/10.1016/j.foreco.2015.06.021
Pegg GS, Brawner JT, Lee DJ (2013) Screening Corymbia populations for resistance to Puccinia psidii.https://doi.org/101111/ppa.12097

Potts BM, Barbour RC, Hingston AB, Vaillancourt RE (2003) Turner Review No 6 Genetic Pollution of Native Eucalypt Gene Pools - Identifying the Risks. Australian Journal of Botany 51: 1-25.

Pryor LD, Johnson LAS (1971) A Classification of the Eucalypts (Australian National University Press, Canberra).

Queiroz TB, Campoe OC, Montes CR, Álvares CA, Cuartas MZ, Guerrini IA (2020) Temperature thresholds for Eucalyptus genotypes growth across tropical and subtropical ranges in South America. Forest Ecology and Management 472: 118248. https://doi.org/10.1016/j.foreco.2020.118248

Resende MDV, Assis TF, Grattapaglia D, Pires IE (2014) Genética e Melhoramento do Eucalipto p. 103-119, In: Eucaliptocultura no Brasil - Silvicultura, Manejo e Ambiencia SIF UFV eds.

Rezende GDSP, Resende MDV, Assis TF (2014) pp 393-424 Eucalyptus breeding for Clonal Forestry, in: Fenning, $T$ (ed.), Challenges and Opportunities for the World's Forests in the 21st Century, Forestry Science 81, doi 10.1007/97894-007-7076-8_16, @ Springer Science+Business Media Dordrecht 2014 Silva PHM, Junqueira LR, Araujo MJ, Wilcken CF, Moraes MLT, Paula RC (2019) Susceptibility of eucalypt taxa to a natural infestation of Leptocybe invasa. New Forests. https://doi.org/10.1007/s11056-019-09758-1

Tarigan M, Roux J, van Wyk M, Tjahjono B, Wingfield MJ (2011) A new wilt and die-back disease of Acacia mangium associated with Ceratocystis manginecans and C. acaciivora sp nov. in Indonesia. South African Journal of Botany. 77: 292-304. https://doi.org/10.1016/j.sajb.2010.08.006

Vigneron P, Bouvet J-M, Gouma R, Saya AR, Gion J-M, Verhaegen D (2000) Eucalypt hybrids breeding in Congo. In: Hybrid breeding and genetics of forest trees: QFRI-CRS Symposium, Noosa, Queensland, Australia, 9-14 April, 2000. (Eds.: Dungey, HS, MJ Dieters, and DG Nikles Department of Primary Industries, Brisbane)

Water for a Healthy Country, Taxon Attribute Profiles - Eucalyptus camaldulensis Dehnh. River Red Gum, 9 p. revised 2004. anbg.gov.au/cpbr/WfHC/Eucalyptus camaldulensis/ 